\title{
Structural, non-linear optical and dielectric properties of LPAHCl-manganese sulphate and cadmium chloride co-crystals
}

\author{
K. Selvarani ${ }^{1,2, *}$, R. MAhalakshmi ${ }^{2}$, B. Thanuja ${ }^{1}$ \\ ${ }^{1}$ Sri Sairam Engineering College, Sai Leo Nagar, West Tambaram, Chennai-44, India \\ ${ }^{2}$ G.K.M. College of Engineering and Technology, GKM Nagar, Perungalathur, Chennai-63, India
}

\begin{abstract}
Co-crystals of L-phenylalanine hydrochloride (LPAHCl) were grown by slow evaporation technique in the presence of manganese sulphate and cadmium chloride. Crystallinity of the grown crystals was confirmed by single crystal X-ray diffraction. Optical transmission spectra showed very high transmittance in the entire visible region. The cut-off wavelength was observed at $250 \mathrm{~nm}$ for both the crystals. The optical band gap energy was found to be $4.37 \mathrm{eV}$ and $4.31 \mathrm{eV}$ for the grown co-crystals of LPAHCl with $\mathrm{MnSO}_{4}$ and $\mathrm{CdCl}_{2}$, respectively. The second harmonic generation of the grown crystals was confirmed by Kurtz and Perry powder SHG method and compared with KDP. The frequency dependent dielectric properties of the co-crystals were studied at different temperatures.
\end{abstract}

Keywords: single XRD; UV-Vis; FT-IR; NLO; dielectrics studies

\section{Introduction}

Single crystals with high second order optical nonlinearity find wide applications in the field of LASER and optoelectronic technologies [1-3]. Within the last decades much progress has been made in the development of these NLO organic materials having large nonlinear optical coefficients. However, weak van der Waals and hydrogen bonds with conjugated electrons constitute most of the organic NLO crystal. Aminoacids are favorable materials for NLO applications as they contain a proton donor carboxylic acid $(\mathrm{COOH})$ group and proton acceptor $\left(\mathrm{NH}_{2}\right)$ group [4]. A lot of natural aminoacids exhibit the nonlinear optical properties. The importance of aminoacids in NLO applications is due to the fact that all the aminoacids have chiral symmetry and crystallize in non-centrosymmetric space groups [5]. Among them, L-phenylalanine is an essential protein aminoacid which is used by the body to build neuro transmitters [6]. Recent interest is centered on semi-organic crystals,

*E-mail: selva_physics@yahoo.com which have the mixed properties of both inorganic and organic crystals. Different compounds with L-phenylalanine such as semiorganic NLO materials have been reported [7].

The present paper is focused on growing single crystals of $\mathrm{LPAHCl}$ in the presence of $\mathrm{MnSO}_{4}$ and $\mathrm{CdCl}_{2}$ by slow evaporation technique. The crystals were characterized by single crystal X-ray diffraction, UV-Vis and FT-IR analyses. The grown crystals were subjected to second harmonic generation and dielectrics studies and the obtained results were compared. LPAHCl with manganese sulphate crystallizes in orthorhombic P2 ${ }_{1} 2_{1} 2_{1}$ space group and $\mathrm{LPAHCl}$ with cadmium chloride crystallizes in monoclinic $\mathrm{P} 2{ }_{1}$ space group. Optical transmittance spectra show high transmittance in the entire visible region and the cut off wavelength of $250 \mathrm{~nm}$ for both the crystals. Optical band gaps of the grown crystals LPAHCl with manganese sulphate and cadmium chloride were calculated. SHG efficiency of $\mathrm{LPAHCl}$ with $\mathrm{CdCl}_{2}$ is higher than that of $\mathrm{LPAHCl}$ with $\mathrm{MnSO}_{4}$. Dielectric constant and dielectric loss were determined and found to be low at higher frequency for both the crystals. 


\section{Experimental}

The starting materials for synthesis were of AR grade and used as purchased. Both L-phenylalanine and manganese sulphate as well as L-phenylalanine and cadmium chloride were taken in stoichiometric ratios and dissolved separately in a mixed solvent composed of hydrochloric acid and double distilled water. The prepared saturated solutions were filtered using Whatman filter paper, collected in a crystal growing vessel, covered with a perforated paper and set aside undisturbed for evaporation. The crystals were grown by slow evaporation technique. Optically transparent LPAHCl in the presence of $\mathrm{MnSO}_{4}$ and $\mathrm{CdCl}_{2}$ crystals of dimension $30 \times 2 \times 2 \mathrm{~mm}^{3}$ and $30 \times 19 \times 2 \mathrm{~mm}^{3}$ were harvested after 25 and 35 days, respectively. The grown co-crystals of LPAHCl are shown in Fig. 1a and Fig. 1b.

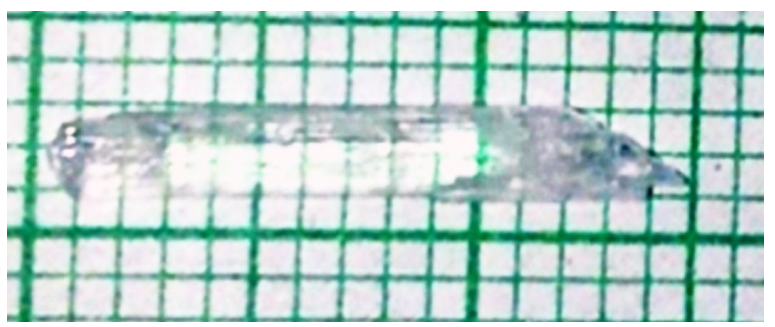

(a)

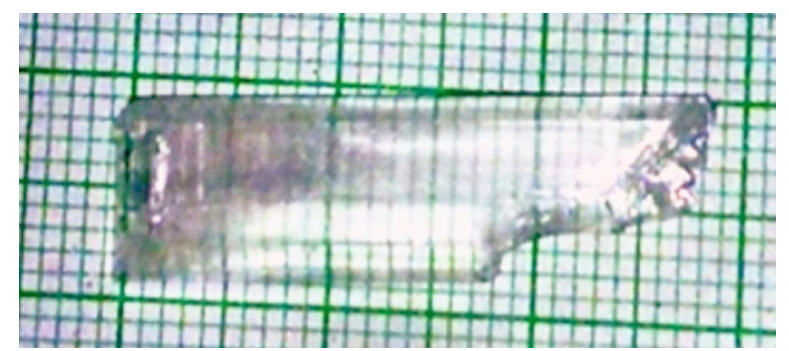

(b)

Fig. 1. (a) as-grown crystal of $\mathrm{LPAHCl}+\mathrm{MnSO}_{4}$ and (b) as-grown crystal of $\mathrm{LPAHCl}+\mathrm{CdCl}_{2}$.

\section{Results and discussion}

\subsection{Structure resolving and refinement}

In order to assess the structure of synthesized crystals of $\mathrm{LPAHCl}$ in the presence of $\mathrm{MnSO}_{4}$ and $\mathrm{CdCl}_{2}$, single crystal XRD studies have been carried out using BRUKER AXS KAPPA APEX (II) CCD diffractometer with MoK $\alpha$ (wavelength of $0.71073 \AA$ ) radiation.

From the single crystal analysis, it was observed that the $\mathrm{LPAHCl}$ with $\mathrm{MnSO}_{4}$ crystal belongs to orthorhombic system with non-centrosymmetric space group, $\mathrm{P} 2{ }_{1} 2_{1} 2_{1}$. Similarly, LPAHCl with $\mathrm{CdCl}_{2}$ crystallized in monoclinic space group $\mathrm{P} 2{ }_{1}$. The data were collected and the final unit cell parameters were calculated and refined. They match well with the reported values of LPAHCl [8-10]. Most of the bond lengths, bond angles and torsion angles are in good agreement with standard values reported in the literature [11]. The comparison of bond lengths, bond angles, torsion angles and hydrogen bonds values for obtained compounds and $\mathrm{LPAHCl}$ as a reference are listed in Table 1, Table 2, Table 3, Table 4, Table 5 and Table 6 . The electronic configuration of $\mathrm{Mn}$ and $\mathrm{Cd}$ salts results in the formation of co-crystals of LPAHCl with different space groups. The structures of the crystals $\mathrm{LPAHCl}$ with $\mathrm{MnSO}_{4}$ and $\mathrm{CdCl}_{2}$ are shown in Fig. $2 \mathrm{a}$ and Fig. 2b. They are also further confirmed by FT-IR spectra.

\subsection{FT-IR spectra}

IR spectra for both compounds of LPAHCl in the presence of $\mathrm{MnSO}_{4}$ and $\mathrm{CdCl}_{2}$ were recorded using PERKIN-ELMER spectrometer in the range of $4000 \mathrm{~cm}^{-1}$ to $400 \mathrm{~cm}^{-1}$ using the $\mathrm{KBr}$ pellet technique with a resolution of $1.0 \mathrm{~cm}^{-1}$. The recorded spectra of $\mathrm{LPAHCl}$ in presence of $\mathrm{MnSO}_{4}$ and $\mathrm{CdCl}_{2}$ are shown in Fig. 3a and Fig. 3b.

In the FT-IR spectra of $\mathrm{LPAHCl}$ with $\mathrm{MnSO}_{4}$ and $\mathrm{CdCl}_{2}$, the $-\mathrm{OH}$ and $-\mathrm{NH}$ stretching modes are found at $2974 \mathrm{~cm}^{-1}$ and $3067 \mathrm{~cm}^{-1}$ respectively. The bands around $2697 \mathrm{~cm}^{-1}$ and $2737 \mathrm{~cm}^{-1}$ are assigned to the aromatic $\mathrm{C}-\mathrm{H}$ stretching modes. The symmetric stretching mode of the carbonyl group and $\mathrm{C}-\mathrm{N}$ appears as the broad band around at $1736 \mathrm{~cm}^{-1}$ and $1624 \mathrm{~cm}^{-1}$ with very strong intensity.

In the solid state, $\mathrm{LPAHCl}$ with $\mathrm{CdCl}_{2}$ exhibits intramolecular bonding in Fig. 3b. This is supported by the appearance of $-\mathrm{OH}$ as a sharp 
Table 1. Cell parameters of LPAHCL and LPAHCL with $\mathrm{MnSO}_{4}$ and $\mathrm{CdCl}_{2}$.

\begin{tabular}{|c|c|c|c|}
\hline Parameter & LPAHCl & $\mathrm{LPAHCl}+\mathrm{MnSO}_{4}$ & $\mathrm{LPAHCl}+\mathrm{CdCl}_{2}$ \\
\hline Formula & $\mathrm{C}_{9} \mathrm{H}_{12} \mathrm{NO}_{2} \mathrm{Cl}$ & $\mathrm{C}_{9} \mathrm{H}_{12} \mathrm{NO}_{2} \mathrm{Cl}$ & $\mathrm{C}_{9} \mathrm{H}_{12} \mathrm{NO}_{2} \mathrm{Cl}$ \\
\hline Space group & $\mathrm{P} 2{ }_{1} 2_{1} 2_{1}$ & $\mathrm{P} 2{ }_{1} 2_{1} 2_{1}$ & $\mathrm{P} 2{ }_{1}$ \\
\hline Cell lengths $[\AA ̊]$ & $\begin{array}{c}\mathrm{a}=27.762[6] \\
\mathrm{b}=5.376[4] \\
\mathrm{c}=7.039[1] \\
\alpha=90^{\circ}\end{array}$ & $\begin{array}{c}\mathrm{a}=27.697[5] \\
\mathrm{b}=5.380[3] \\
\mathrm{c}=7.036[4] \\
\alpha=90^{\circ}\end{array}$ & $\begin{array}{c}\mathrm{a}=27.703[4] \\
\mathrm{b}=5.389[7] \\
\mathrm{c}=7.0549[3] \\
\alpha=90^{\circ}\end{array}$ \\
\hline Cell angles & $\begin{array}{l}\beta=90^{\circ} \\
\gamma=90^{\circ}\end{array}$ & $\begin{array}{l}\beta=90^{\circ} \\
\gamma=90^{\circ}\end{array}$ & $\begin{array}{c}\beta=90.092^{\circ} \\
\gamma=90^{\circ}\end{array}$ \\
\hline Cell volume $\left[\AA^{3}\right]$ & 1050 & 1048.48 & 1053.35 \\
\hline $\mathrm{Z}$ & - & 12 & 4 \\
\hline $\mathrm{R}$-factor [\%] & - & 6.23 & 3.57 \\
\hline
\end{tabular}

Table 2. Bond length $\mathrm{LPAHCl}$ with $\mathrm{MnSO}_{4}$ and $\mathrm{CdCl}_{2}$.

\begin{tabular}{|c|c|c|c|}
\hline \multicolumn{2}{|c|}{$\mathrm{LPAHCl}+\mathrm{MnSO}_{4}$} & \multicolumn{2}{|c|}{$\mathrm{LPAHCl}+\mathrm{CdCl}_{2}$} \\
\hline Atoms & Bond length $[\AA]$ & Atoms & Bond length $[\AA]$ \\
\hline $\mathrm{C} 2-\mathrm{C} 3$ & 1.42 & $\mathrm{C} 2-\mathrm{C} 3$ & 1.33 \\
\hline $\mathrm{C} 4-\mathrm{C} 5$ & 1.40 & $\mathrm{C} 4-\mathrm{C} 5$ & 1.38 \\
\hline C5-C6 & 1.42 & $\mathrm{C} 5-\mathrm{C} 6$ & 1.37 \\
\hline $\mathrm{C} 9-\mathrm{O} 1$ & 1.21 & $\mathrm{C} 9-\mathrm{O} 1$ & 1.325 \\
\hline C9-O2 & 1.34 & C9-O2 & 1.195 \\
\hline
\end{tabular}

Table 3. Bond angles $\mathrm{LPAHCl}$ with $\mathrm{MnSO}_{4}$ and $\mathrm{CdCl}_{2}$.

\begin{tabular}{lcc}
\hline \multirow{2}{*}{ Atoms } & \multicolumn{2}{c}{ Bond angles $\left[{ }^{\circ}\right]$} \\
\cline { 2 - 3 } & LPAHCl $+\mathrm{MnSO}+P A H C l+\mathrm{CdCl}_{2}$ \\
\hline \hline C7-C8-C9 & 113 & 114.2 \\
C9-C8-N1 & 105.7 & 106.6 \\
C8-C9-01 & 128 & 110.9 \\
C8-C9-O2 & 115 & 124.7 \\
O1-C9-O2 & 117 & 124.4 \\
\hline
\end{tabular}

intense band at $3067 \mathrm{~cm}^{-1}$. CO stretching frequency is found to have been decreased to $1622 \mathrm{~cm}^{-1}$. This is due to the protonated nitrogen group in $\mathrm{LPAHCl}$ with $\mathrm{CdCl}_{2}$ as shown in Fig. 4 a. The appearance of broad $-\mathrm{OH}$ absorption peak at $2974 \mathrm{~cm}^{-1}$ in $\mathrm{LPAHCl}$ with $\mathrm{MnSO}_{4}$ exhibits intermolecular bonding (Fig. 3a). This is due to the existence of $\mathrm{LPAHCl}$ with $\mathrm{MnSO}_{4}$ in acid form as shown in Fig. 4b.

\subsection{UV-Vis spectroscopic studies}

The optical transmission spectra of LPAHCl in the presence of $\mathrm{MnSO}_{4}$ and $\mathrm{CdCl}_{2}$ are presented in Fig. 5. The UV cut-off wavelengths of both the samples are found to be $250 \mathrm{~nm}$ and the transmission is very high throughout the entire visible region and part of IR region. The optical band gap has been obtained using Tauc plot [12] by plotting the graphs between $(\alpha h v)^{2}$ versus hv in Fig. 6. From the graphs, the optical energy gap of LPAHCl in the presence of $\mathrm{MnSO}_{4}$ and $\mathrm{CdCl}_{2}$ was determined as $4.37 \mathrm{eV}$ and $4.31 \mathrm{eV}$, respectively.

\subsection{NLO studies}

The second harmonic generation (SHG) test on the LPAHCl crystal in the presence of $\mathrm{MnSO}_{4}$ and $\mathrm{CdCl}_{2}$ has been performed by Kurtz and Perry powder SHG method. The fundamental beam of Nd:YAG laser with $1064 \mathrm{~nm}$ wavelength, pulse

Table 4. Torsion angles $\mathrm{LPAHCl}$ with $\mathrm{MnSO}_{4}$ and $\mathrm{CdCl}_{2}$.

\begin{tabular}{ccc}
\hline \multirow{2}{*}{ Atoms } & \multicolumn{2}{c}{${\left.\text { Torsion angles [ }{ }^{\circ}\right]}^{\circ}$} \\
\cline { 2 - 3 } & LPAHCl $+\mathrm{MnSOLPAHCl}+\mathrm{CdCl}_{2}$ \\
\hline \hline C1-C6-C7-C8 & -97 & 82.8 \\
C5-C6-C7-C8 & 84 & -96.9 \\
C6-C7-C8-N1 & 58 & 60.0 \\
C7-C8-C9-O1 & 124 & -57.9 \\
C7-C8-C9-O2 & -57 & 123.3 \\
\hline
\end{tabular}


Table 5. Bonding interactions of $\mathrm{LPAHCl}$ with $\mathrm{MnSO}_{4}$.

\begin{tabular}{|c|c|c|c|c|}
\hline \multirow[t]{2}{*}{ Bonding interactions } & \multicolumn{4}{|c|}{$\mathrm{LPAHCl}$ with $\mathrm{MnSO}_{4}$} \\
\hline & $\mathrm{D}-\mathrm{H}$ & H...A & D...A & $\mathrm{D}-\mathrm{H} \ldots \mathrm{A}$ \\
\hline $\mathrm{N}(1)-\mathrm{H}(1 \mathrm{~N}) . . \mathrm{Cl}(1)$ & 1.39 & 1.79 & 3.1545 & 164 \\
\hline $\mathrm{N}(1)-\mathrm{H}(2 \mathrm{~N}) . . \mathrm{Cl}(1)$ & 0.96 & 2.38 & 3.3445 & 177 \\
\hline $\mathrm{N}(1)-\mathrm{H}(3 \mathrm{~N}) . . \mathrm{Cl}(1)$ & 1.08 & 2.51 & 3.2466 & 125 \\
\hline $\mathrm{N}(1)-\mathrm{H}(3 \mathrm{~N}) . . \mathrm{O}(1)$ & 1.08 & 2.19 & 3.0381 & 134 \\
\hline $\mathrm{C}(8)-\mathrm{H}(8) . . \mathrm{O}(1)$ & 0.98 & 2.38 & 3.2173 & 143 \\
\hline
\end{tabular}
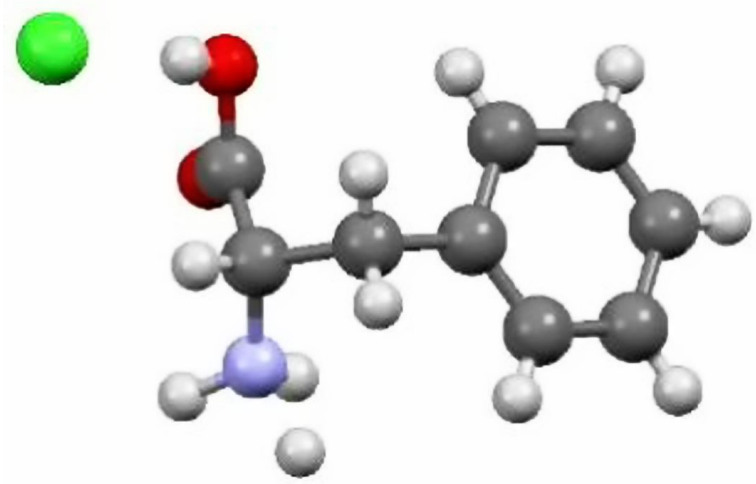

(a)

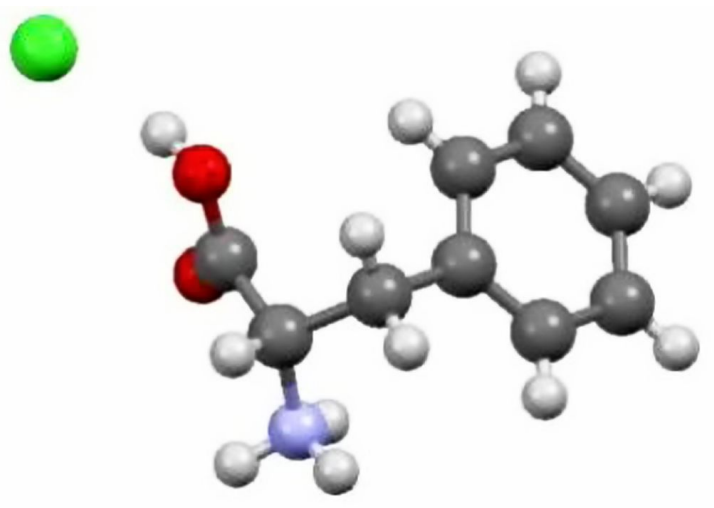

(b)

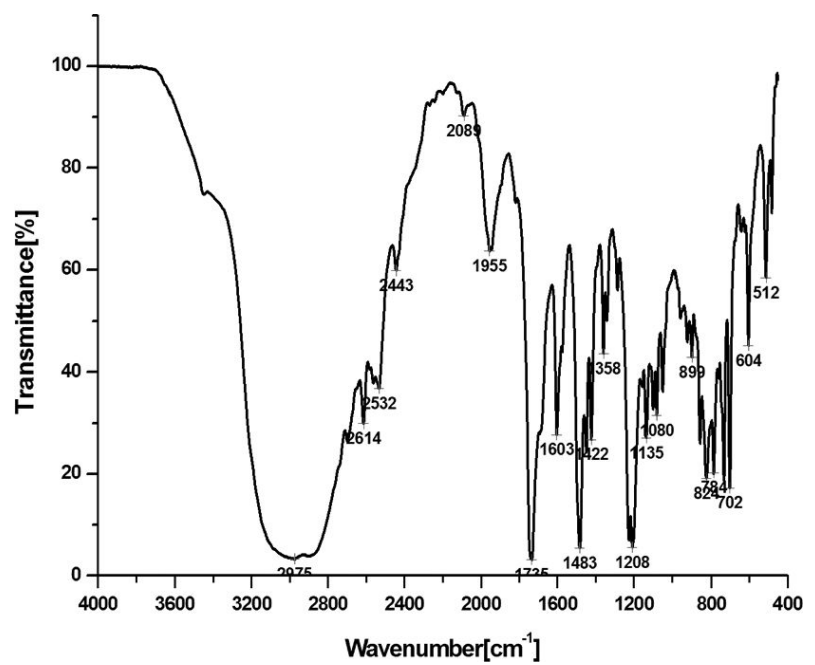

(a)

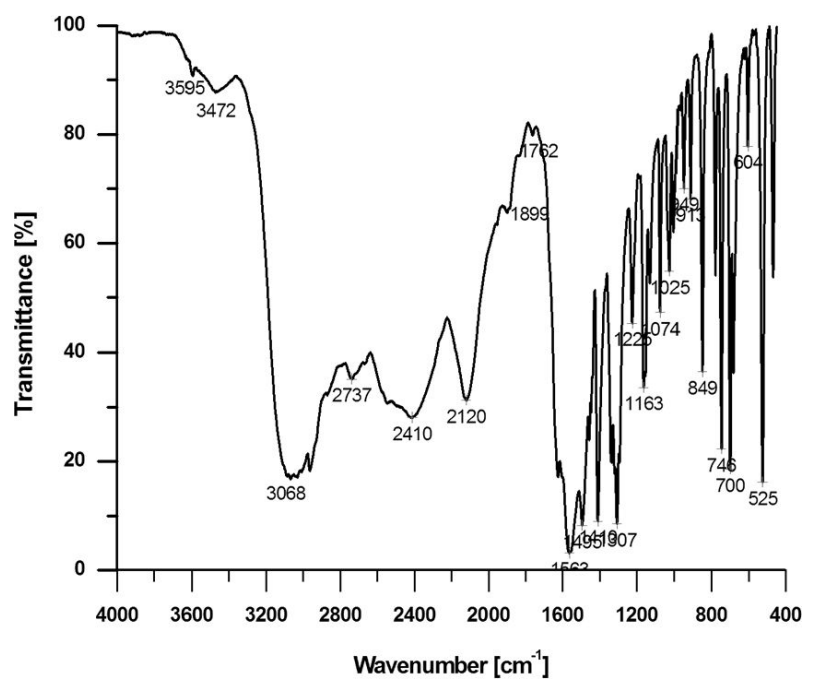

(b)

Fig. 3. (a) FT-IR spectrum of $\mathrm{LPAHCl}$ with $\mathrm{MnSO}_{4}$, (b) FT-IR spectrum of $\mathrm{LPAHCl}$ with $\mathrm{CdCl}_{2}$.

Fig. 2. (a) structure of $\mathrm{LPAHCl}$ with $\mathrm{MnSO}_{4}$ and (b) structure of $\mathrm{LPAHCl}$ with $\mathrm{CdCl}_{2}$.

duration of $8 \mathrm{~ns}$ and $10 \mathrm{~Hz}$ repetition rate was focused onto the powdered sample of LPAHCl in the presence of $\mathrm{MnSO}_{4}, \mathrm{CdCl}_{2}$ and KDP. When the input pulse of $0.68 \mathrm{~J}$ was passing through KDP and the samples, the output signals of $8.8 \mathrm{~mJ}, 3.8 \mathrm{~mJ}$ and $4.0 \mathrm{~mJ}$ were obtained from KDP, LPAHCl crystals in the presence of $\mathrm{MnSO}_{4}$ and $\mathrm{CdCl}_{2}$, respectively. Thus, the NLO efficiency of LPAHCl

crystals in the presence of $\mathrm{MnSO}_{4}$ and $\mathrm{CdCl}_{2}$ is nearly half to that of KDP crystal.

\subsection{Dielectric studies}

The dielectric constant and the dielectric loss of the $\mathrm{LPAHCl}$ in the presence of $\mathrm{MnSO}_{4}$ and $\mathrm{CdCl}_{2}$ crystal were measured at different temperatures using HIOKI 3532-50 LCR HITESTER in the frequency region of $100 \mathrm{~Hz}$ to $5 \mathrm{MHz}$. The sample was placed between two electrodes using silver paste to make it to behave like a parallel plate 
Table 6. Bonding interactions of $\mathrm{LPAHCl}$ with $\mathrm{CdCl}_{2}$.

\begin{tabular}{lcccc}
\hline \multirow{2}{*}{ Bonding interactions } & \multicolumn{4}{c}{ LPAHCl with $\mathrm{CdCl}_{2}$} \\
\cline { 2 - 5 } & $\mathrm{D}-\mathrm{H}$ & $\mathrm{H} \ldots \mathrm{A}$ & $\mathrm{D} \ldots \mathrm{A}$ & $\mathrm{D}-\mathrm{H} \ldots \mathrm{A}$ \\
\hline \hline $\mathrm{N}(1)-\mathrm{H}(1 \mathrm{~N}) . . \mathrm{Cl}(1)$ & 0.89 & 2.46 & 3.3343 & 168 \\
$\mathrm{~N}(1)-\mathrm{H}(2 \mathrm{~N}) . . \mathrm{Cl}(1)$ & 0.92 & 2.41 & 3.2581 & 153 \\
$\mathrm{~N}(1)-\mathrm{H}(2 \mathrm{~N}) . . \mathrm{O}(2)$ & 0.92 & 2.56 & 3.0580 & 114 \\
$\mathrm{~N}(1)-\mathrm{H}(3 \mathrm{~N}) . . \mathrm{Cl}(1)$ & 0.91 & 2.29 & 3.1726 & 165 \\
$\mathrm{O}(3)-\mathrm{H}(3 \mathrm{O}) . . \mathrm{Cl}(2)$ & 0.86 & 2.14 & 2.9884 & 168 \\
$\mathrm{~N}(2)-\mathrm{H}(4 \mathrm{~N}) . . \mathrm{O}(4)$ & 0.92 & 2.49 & 3.0522 & 120 \\
$\mathrm{C}(8)-\mathrm{H}(8) . . \mathrm{O}(2)$ & 0.98 & 2.42 & 3.2605 & 143 \\
\hline
\end{tabular}<smiles>CC(Cc1cccc(C[C@@H](N)Cc2ccccc2)c1)C(=O)O</smiles>

Fig. 4. (a) LPAHCl in protonated form and (b) in acidic form.

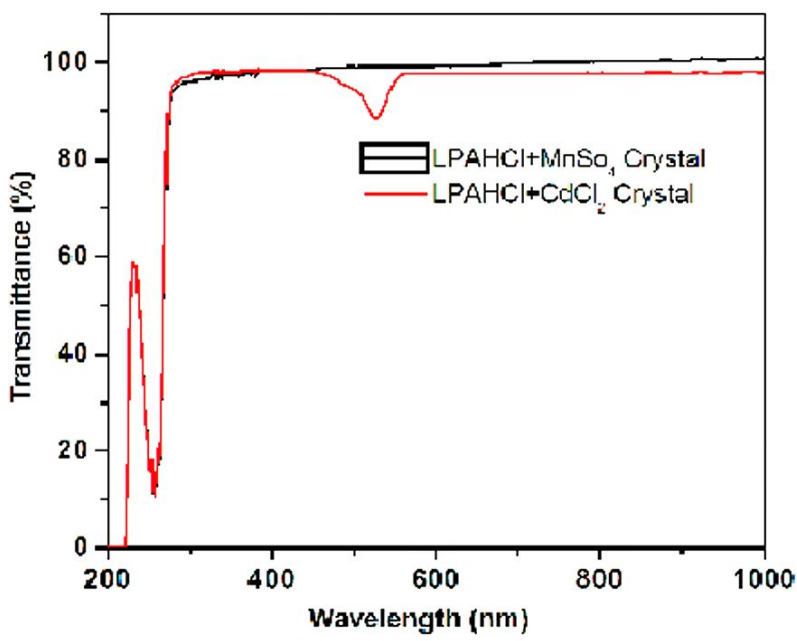

Fig. 5. Transmission spectra of LPAHCl with $\mathrm{MnSO}_{4}$ and $\mathrm{CdCl}_{2}$.

capacitor. The measured dielectric constant $\epsilon^{\prime}$ is higher at the lower frequencies and then decreases with the increasing frequency and saturates for both the crystals as shown in Fig. 7a and Fig. 7b.

The dielectric loss $\epsilon^{\prime \prime}$ decreases with increasing frequency for the grown crystals of LPAHCl in the presence of $\mathrm{MnSO}_{4}$ and $\mathrm{CdCl}_{2}$ as shown in Fig. 8a and Fig. 8b.

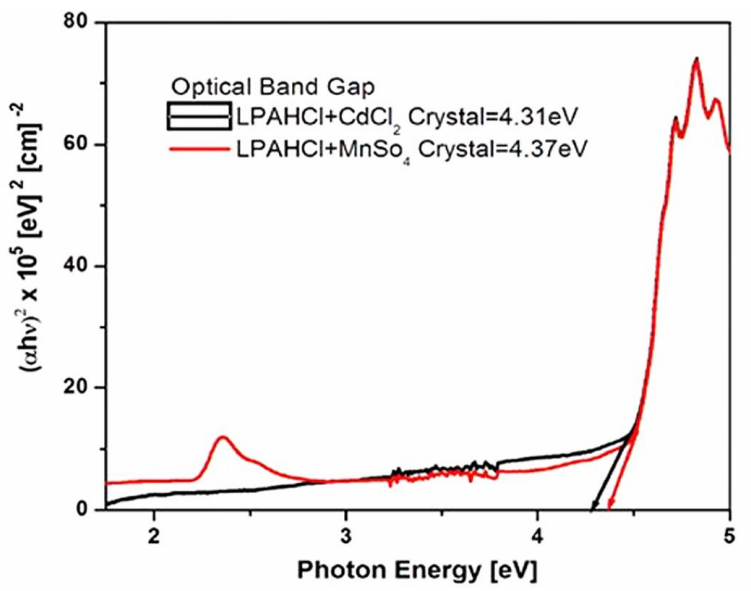

Fig. 6. Band gap determination for $\mathrm{LPAHCl}$ with $\mathrm{MnSO}_{4}$ and $\mathrm{CdCl}_{2}$.

The large value of dielectric constant at low frequency is due to the presence of space charge polarization. The dielectric constant decreases with increasing frequency and remains constant. As a result, the dielectric polarization increases causing an increase in $\epsilon^{\prime}$ and $\epsilon^{\prime \prime}$. The behavior of low dielectric constant and dielectric loss at high frequency suggests that the sample is characterized by enhanced optical quality with less defects and this parameter is of vital importance for NLO applications.

\section{Conclusions}

Single crystals of LPAHCl have been studied in the presence of $\mathrm{MnSO}_{4}$ and $\mathrm{CdCl}_{2}$ crystallized in orthorhombic and monoclinic space group. The optical-cut off frequencies of both co-crystals are 


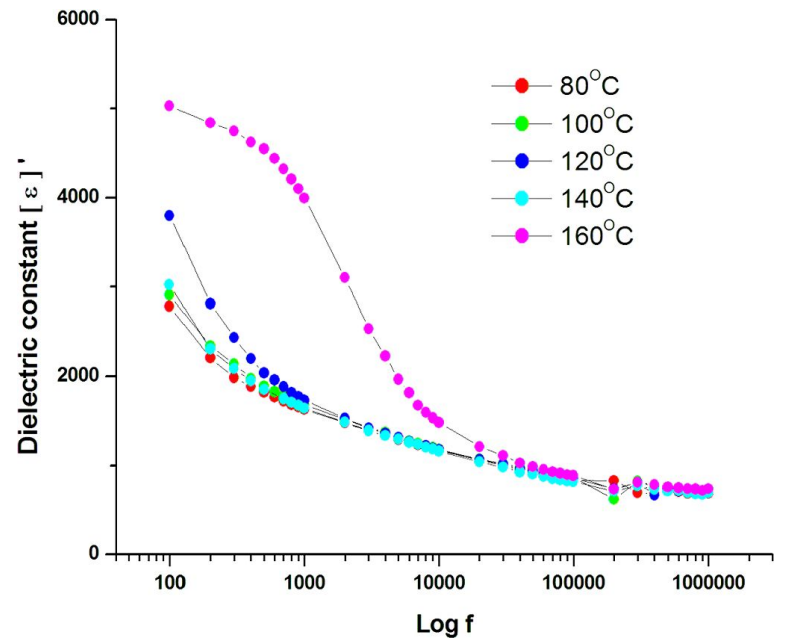

(a)

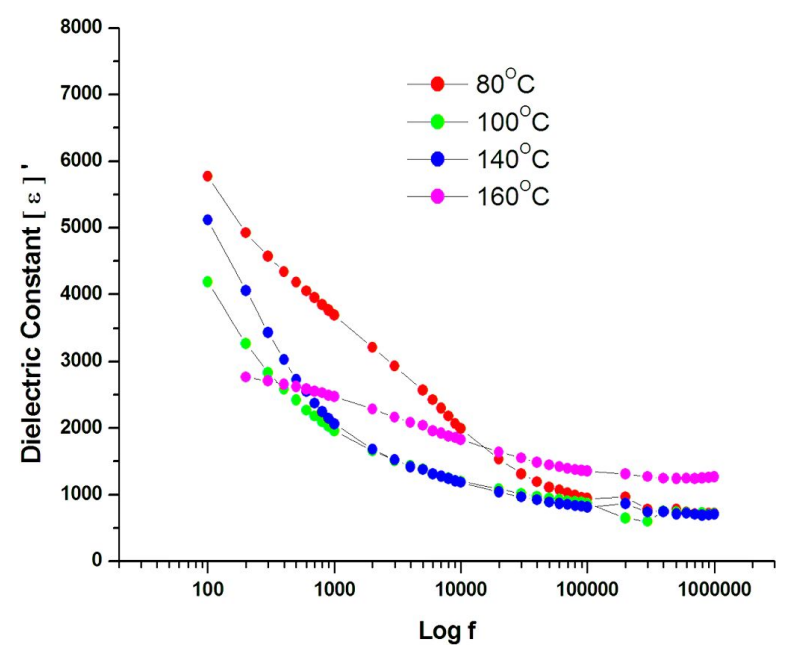

(b)

Fig. 7. Frequency dependence of dielectric constant of LPAHCl (a) with $\mathrm{MnSO}_{4}$, (b) with $\mathrm{CdCl}_{2}$.

found to be $250 \mathrm{~nm}$. Optical band gap of the grown crystals $\mathrm{LPAHCl}$ with $\mathrm{MnSO}_{4}$ and $\mathrm{CdCl}_{2}$ are $4.37 \mathrm{eV}$ and $4.31 \mathrm{eV}$, respectively. SHG efficiency of $\mathrm{LPAHCl}$ with $\mathrm{CdCl}_{2}$ is slightly higher than that of $\mathrm{LPAHCl}$ with $\mathrm{MnSO}_{4}$. The dielectric constant and dielectric loss have been determined and found to be decreasing with an increase in frequency for both the crystals which shows that the crystals are suitable for NLO application.

\section{Acknowledgements}

The authors thank IIT-MADRAS, Department of Chemistry for providing the facility for single XRD studies and

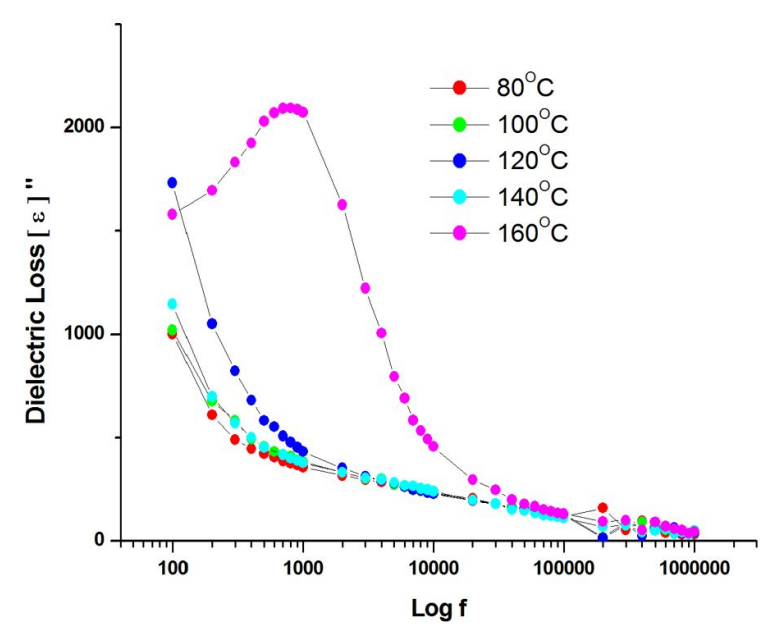

(a)

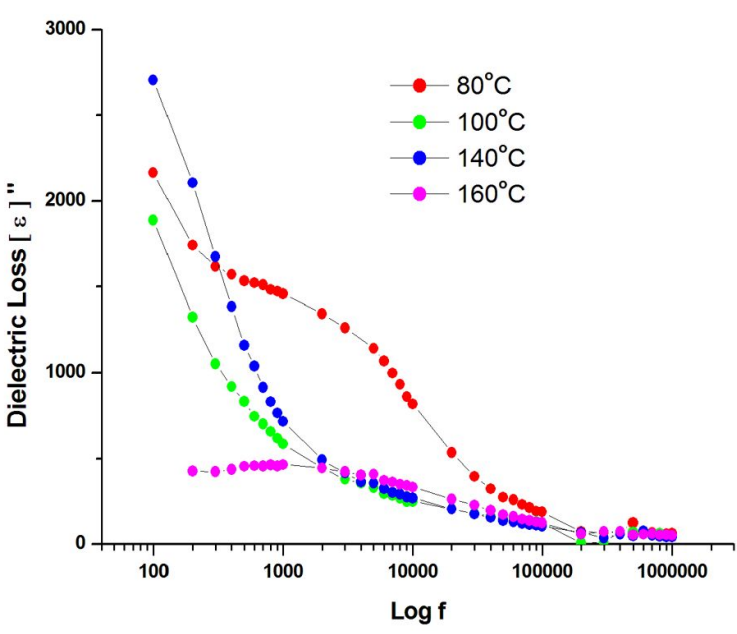

(b)

Fig. 8. Frequency dependence of dielectric loss for $\mathrm{LPAHCl}$ (a) with $\mathrm{MnSO}_{4}$, (b) with $\mathrm{CdCl}_{2}$.

Department of Physics, B.S.ABDUR RAHMAN UNIVERSITY for providing the facility for NLO studies. Also thanks to the Management, Faculty members of Department of Physics for their constant support and encouragement.

\section{References}

[1] Marcy H.O., Warren L.F., Webb M.S., Ebbers C.A., Velsko S.P., Kennedy G.C., Catella G.C., Appl. Opt., 31 (1992), 5051.

[2] Wang X.Q., XU D., YUan D.R., TIAN Y.P., YU W.T., Sun S.Y., YANG Z.H.,FANG Q., LU M.K., Yan Y.X., Meng F.Q., GuO S.Y., Zhang G.H., JiAng M.H., Mater. Res. Bull., 34 (2003), 1999.

[3] Angelimary P.A., Dhanuskodi S., Cryst. Res. Technol., 36 (2001), 1231. 
[4] Marder S.R., John E., SoH N., Galen D. STUCK Y., Materials for Nonlinear Optics, Chemical Perspectives ACS Symposium series No. 455, Washington, DC, 1991.

[5] Bhat M.N., Dharmaprakash S.M., J. Cryst. Growth, 236 (2002), 376.

[6] Mahalakshmi R., Jesuraja S.X., Das J.S., Cryst. Res. Technol., 41 (2006), 780.

[7] Selvarani K., Mahalakshmi R., Int. J. ChemTech Res., 9 (1) (2016), 113.

[8] Yogam F., Vetha Potheher I., Cyrac Peter A., TAMilselvan S., Rajesh L.A., Vimalan M., Sagayaraj P., Adv. Appl. Sci. Res., 2 (1) (2011), 261.
[9] Al-Karaghouli A.R., Koetzle T.F., Acta. Cryst. $B, 31$ (1975), 2461.

[10] Gurskaya G.V., Sov. Phys. Crystallogr., 9 (1965), 709.

[11] Allen F.H., Kennard O., Watson D.G., BramMer L., Orpen G.A., TAYlor R., J. Chem. Soc. Perkin Trans., 2 (1987), S1.

[12] Tauc J., Grigorovici R., Vancu A., Phys. Status Solidi B, 15 (1966), 627.

Received 2016-09-29

Accepted 2018-01-09 